How to Cite: Kamani, V.G., Sujatha, M., \& Daddala, G.B. (2021) Development and validation of a novel stability indicating HPLC method for the separation and determination of darolutamide and its impurities in pharmaceutical formulations. Bulletin of the University of Karaganda - Chemistry, 104(4), 57-68. https://doi.org/10.31489/2021Ch4/57-68

UDC 543.544

\author{
V.G. Kamani ${ }^{*}$, M. Sujatha ${ }^{1}$, G.B. Daddala ${ }^{2}$ \\ ${ }^{I}$ Koneru Lakshmaiah Education Foundation, Vaddeswaram, Guntur, India; \\ ${ }^{2}$ Piramal Pharma Ltd, Ennore, Chennai, Tamil Nadu, India \\ (*Corresponding author's e-mail:venukamani@gmail.com)
}

\title{
Development and validation of a novel stability indicating HPLC method for the separation and determination of darolutamide and its impurities in pharmaceutical formulations
}

\begin{abstract}
This study reports for the first time about a stability indicating RP-HPLC method for analysis of darolutamide and its impurities 1, 2, and 3 in bulk and formulations. The separation was achieved on Phenomenex column with Luna C18 $(250 \mathrm{~mm} \times 4.6 \mathrm{~mm}, 5 \mu \mathrm{m})$ as stationary phase, and $50 \mathrm{mM}$ ammonium acetate: methanol solution 15:80 (v/v) at pH 5.2 as mobile phase at $1.0 \mathrm{~mL} / \mathrm{min}$ flow rate. UV detection was carried at wavelength of $239 \mathrm{~nm}$. In these conditions the retention time of darolutamide and its impurities 1, 2, and 3 was 7.05, 8.90, 4.63 and $5.95 \mathrm{~min}$, respectively. The method was validated for system suitability, range of analysis, precision, specificity, stability, and robustness. Forced degradation study was done through exposure of the analyte to five different stress conditions and the \% degradation was small in all degradation condition. The proposed method can separate and estimate the drug and its impurities in pharmaceutical formulations. Hence, the developed method was suitable for the quantification of darolutamide and can separate and analyse impurities 1 , 2 , and 3 .
\end{abstract}

Keywords: darolutamide, impurity analysis, HPLC method development, method validation, ruggedness, forced degradation study, formulation assay, impurity analysis in Nubeqa ${ }^{\mathbb{B}}$.

\section{Introduction}

Darolutamide (Fig. 1a) is an androgen antagonist (antiandrogen) drug approved for the treatment of non-metastatic castration-resistant prostate cancer (nmCRPC) in combination with medical or surgical castration [1]. It is prescribed for the treatment of nmCRPC in men [2, 3]. Darolutamide acts on androgen receptors (AR) potentiate the growth and survival of prostate cancer cells. It is competitively inhibiting the androgens from binding to their receptors, inhibiting the AR-mediated transcription as well as AR nuclear translocation. Hence, decrees the tumor cell size as well as prostate cancer cell proliferation [4].<smiles>CC(O)c1cc(C(=O)N[C@@H](C)Cn2ccc(-c3ccc(C#N)c(Cl)c3)n2)n[nH]1</smiles>

a) darolutamide<smiles>CC(=O)c1cc(C(=O)N[C@@H](C)Cn2ccc(-c3ccc(C#N)c(Cl)c3)n2)n[nH]1</smiles>

c) impurity 2<smiles>N#Cc1ccc(-c2cc[nH]n2)cc1Cl</smiles>

b) impurity 1<smiles>CC(Cn1ccc(-c2ccc(C#N)c(Cl)c2)n1)NC(=O)OC(C)(C)C</smiles>

d) impurity 3

Figure 1. Chemical structure of darolutamide and its impurities in the study

Pain in extremities, fatigue, rashes, and asthenia are the common side effects of darolutamide. Increased aspartate aminotransferase, decreased neutrophil count and increased bilirubin are the abnormalities associated with darolutamide in terms of laboratory test [5].

Strict control of impurities is necessary for the manufacturing of drug products. These impurities may be present in the materials, formed as by-products during the process of production or appear as degradation 
products during storage. Both actual and potential impurities should be studied and detected by a reliable and convenient method. Though a method was referred to in a patent of Takeda, the practicability of this method has not been verified [6].

A literature review of the available analytical methods for darolutamide analysis confirms that there are few analytical methods available for the assessment of darolutamide along with its active metabolites in biological samples using HPLC [7] and LC-MS / MS [8-11] methods. The main disadvantages of the previously developed methods are the reported methods that were insufficient to separate the potential impurities of darolutamide. The applicability of the reported methods were summarised in Table 1.

Table 1

Comparison of the literature methods and reason for proposal of new method for analysis of darolutamide

\begin{tabular}{|c|c|l|l|}
\hline S No & $\begin{array}{c}\text { Reference } \\
\text { method }\end{array}$ & \multicolumn{1}{|c|}{ Reported method applicability } & $\begin{array}{l}\text { Reason for proposal of new meth- } \\
\text { od }\end{array}$ \\
\hline 1 & $\begin{array}{c}\text { Ashok et al., } \\
2018 \text { [7] }\end{array}$ & $\begin{array}{l}\text { HPLC method reported for the simultaneous estimation of } \\
\text { darolutamide along with other drugs such as apalutamide, } \\
\text { enzalutamide, N-desmethylenzalutamide in mice plasma } \\
\text { and in pharmacokinetic studies }\end{array}$ & $\begin{array}{l}\text { The method is not suitable for the } \\
\text { separation of darolutamide impuri- } \\
\text { ties }\end{array}$ \\
\hline 2 & $\begin{array}{c}\text { Neraj et al., } \\
2018 \text { [8] }\end{array}$ & $\begin{array}{l}\text { LC-MS method reported for the estimation of } \\
\text { enzalutamide, N-desmethylenzalutamide, darolutamide in } \\
\text { mice plasma. }\end{array}$ & $\begin{array}{l}\text { LC-MS is expensive than the } \\
\text { HPLC and the reported method } \\
\text { not suitable for the separation of } \\
\text { darolutamide impurities. }\end{array}$ \\
\hline 3 & $\begin{array}{c}\text { Sreekanth et } \\
\text { al., 2017 [9] }\end{array}$ & $\begin{array}{l}\text { LC-MS/MS-ESI method reported for simultaneous quan- } \\
\text { tification of darolutamide and its active metabolite, ORM- } \\
15341 \text { in mice plasma and its application to a pharmaco- } \\
\text { kinetic study }\end{array}$ & $\begin{array}{l}\text { Reported method only suitable for } \\
\text { separation of darolutamide and its } \\
\text { active metabolite only and can not } \\
\text { separate the impurities }\end{array}$ \\
\hline 4 & $\begin{array}{c}\text { Suresh et al., } \\
2018 \text { [10] }\end{array}$ & $\begin{array}{l}\text { LC-MS/MS method reported for simultaneous quantita- } \\
\text { tion of enzalutamide, N-desmethylenzalutamide, } \\
\text { opalutamide, darolutamide and ORM-15341 in mice } \\
\text { plasma as well as pharmacokinetic study. }\end{array}$ & $\begin{array}{l}\text { LC-MS is expensive than the } \\
\text { HPLC and the reported method } \\
\text { not suitable for the separation of } \\
\text { darolutamide impurities }\end{array}$ \\
\hline 5 & $\begin{array}{c}\text { Narayanan et } \\
\text { al., 2018 [11] }\end{array}$ & $\begin{array}{l}\text { LC-MS/MS-ESI method for the simultaneous quantifica- } \\
\text { tion of darolutamide and its optical isomer 1 and 2 in mice } \\
\text { plasma as well as pharmacokinetic study. }\end{array}$ & $\begin{array}{l}\text { The reported method only suitable } \\
\text { for the separation of optical iso- } \\
\text { mers of darolutamide and is not } \\
\text { applicable for the separation of } \\
\text { impurities of darolutamide }\end{array}$ \\
\hline
\end{tabular}

Thus, the present work aimed to develop a simple and precise analytical HPLC method for the estimation of darolutamide and its impurities 1,2 and 3. The molecular structure of darolutamide impurities 1, 2 and 3 in the study were given in Figure $1 b, 1 c$ and $1 d$ respectively. The method has been validated for Nubeqa ${ }^{\circledR}$ a newly introduced tablet dosage form of darolutamide.

\section{Experimental}

Reagents:

The pure standard of drug darolutamide (98.85\% purity), impurity 1, 2 and 3 in the study along with the formulation dosage form (Nubeqa ${ }^{\circledR}-300 \mathrm{mg}$ ) were obtained from Bayer Pharmaceuticals Private Limited, Thane West, Maharashtra. The HPLC grade methanol, acetonitrile, and ultra-pure (Milli- $\mathrm{Q}^{\circledR}$ ) water were obtained from Merck chemicals, Mumbai.

\section{Instrumentation:}

HPLC analysis of darolutamide and its impurities was performed on Agilent 1100 (USA) HPLC equipped with Quaternary pump (G 1311A) for solvent delivery, autosampler with thermostatic (G 1329A) having $0.1-1500 \mu \mathrm{L}$ of sample injection capacity and UV detector (G 1314A). Agilent chemical station LC software was used for integrating the chromatogram.

Preparation of solutions:

Darolutamide and impurity solutions:

A standard stock solution of darolutamide and its studied impurities 1,2 and 3 were prepared separately by accurately weighing of $50 \mathrm{mg}$ of the compound and dissolving in $50 \mathrm{~mL}$ of methanol solvent. From this solution, selected and required concentration of darolutamide and its impurities were prepared separately. 
Then the mixed standard solution was prepared by mixing equal volumes of concentrations of standard and impurities.

Formulation solution:

Tablets of Nubeqa ${ }^{\circledR}$ brand containing $300 \mathrm{mg}$ of darolutamide was powdered using a sterile mortor and pestle. Then, an amount of tablet powder equivalent to $50 \mathrm{mg}$ of darolutamide was accurately weighed and dissolved in $50 \mathrm{~mL}$ solvent applyng sonicator and filtered through $0.45 \mu$ membrane filter. Afterwards it was diluted while doing the formulation analysis.

\section{Method Development:}

Based on a literature review, it has identified that there is no analytical method reported for assay of darolutamide and its impurities. The method specified in the regulatory document by the manufactures of the standard, as well as formulation were not available easily. Thus, the present work was aimed to develop a simple and accurate HPLC method for simultaneous assay of darolutamide and its impurities.

In the initial stage of method development, the suitable detector wavelength for the simultaneous detection of darolutamide and its impurities was determined using UV — visible spectrophotometer. The isoabsorption wavelength of darolutamide and its impurities was selected as suitable wavelength in the study. Then by keeping the detector wavelength as constant, different configurations of stationary phases for the separation of darolutamide and its impurities were examined. After that, the composition, $\mathrm{pH}$ and flow rate of the mobile phase was optimised. In each cases, the resolution between the compounds, the shape of the individual peak, base line throughout the run time and the system suitability conditions for each peak corresponds to all the analytes in the study was summarised. The conditions that provide the best chromatographic results were selected as appropriate for the validation study [12-14].

\section{Method Validation:}

Standard solution containing darolutamide and its impurities at recovery ranges was analysed for the evaluation of the system suitability of the method. The acceptance developed method should have the system suitability parameters such as asymmetric factor $(<2)$, plate count $(>2000)$, and resolution factor $(>2)$.

A series of darolutamide standard stock solutions containing $1 \%$ of each studied impurity was prepared separately and analysed in the developed method. The calibration plot was constructed using peak area of the resultant chromatograms vs concentration of the analyte prepared. The range of the method was determined using least square analysis and the correlation coefficient and regression equation was calculated.

The accuracy/recovery of the method was determined by spiked recovery at $50 \%, 100 \%$ and $150 \%$ spiked levels in the calibration range. The $\%$ recovery in each spiked level for darolutamide and its impurities were calculated separately by comparing with standard calibration results and a $\%$ recovery of less than 2 was considered as accurate.

The standard solution of darolutamide with its impurities in the calibration was analysed six times in the same day for intraday precision, six times in three different days for interday precision and six times in the day with change in three different analysts for ruggedness study. The \% relative standard deviation (\% RSD) of the peak areas observed in each study was calculated for darolutamide and its impurities separately and the $\%$ RSD of less than 2 was considered as acceptable.

The influence of small change in the analytical conditions on the separation and quantification of darolutamide and its impurities was determined in robustness study. The $\pm 5 \mathrm{~mL}$ change in organic modifier, \pm 0.1 factor change in mobile phase $\mathrm{pH}$ and $\pm 5 \mathrm{~nm}$ change in detector wavelength was study and the $\%$ change in the peak area of darolutamide and its impurities was calculated in each changed condition and a $\%$ change of less than 2 was considered as the method is robust.

Forced degradation study was conducted for determining the efficiency of the developed method for the separation and detection of unknown impurities/stress degradation compounds formed during the degradation study. $50 \mathrm{mg}$ of standard drug darolutamide was mixed with $50 \mathrm{~mL}$ of $0.1 \mathrm{~N} \mathrm{HCl}, 0.1 \mathrm{~N} \mathrm{NaOH}$ and $3 \%$ hydrogen peroxide solution separately for $24 \mathrm{~h}$ in acidic, basic and oxidative degradation study. Then the solution was neutralized and diluted to standard concentration. $50 \mathrm{mg}$ of standard drug darolutamide was kept in an air oven at $60{ }^{\circ} \mathrm{C}$ for $24 \mathrm{~h}$ in thermal degradation study and kept under UV light at $254 \mathrm{~nm}$ for $24 \mathrm{~h}$ for photolytic degradation study. Then it was diluted to standard concentration and the degradation solutions were analysed in the developed method. The number of degradation compounds formed and the $\%$ of degradation was calculated by comparing with unstressed results of darolutamide.

The sensitivity of the method for the detection of impurities in the darolutamide was confirmed by determining limit of detection (LOD) and limit of quantification (LOQ). The applicability of the developed 
method for the detection and quantification of impurities in formulation was confirmed by analysing the formulation solution prepared from cream formulation of darolutamide (Nubeqa ${ }^{\circledR}-300 \mathrm{mg}$ ) [15-18].

\section{Results and Discussions}

The summary of the method developed for the separation and quantification of darolutamide and its impurities was given in Table 2 .

Table 2

Method development conditions studied in the optimization process

\begin{tabular}{|c|c|c|c|}
\hline S.No & Method conditions & Chromatographic result observed & Conclusion \\
\hline 1 & \begin{tabular}{llrr}
\multicolumn{3}{l}{ MP: Methanol and sodium acetate buffer $\mathrm{pH} 5.6$} \\
in $50: 50 \quad(\mathrm{v} / \mathrm{v}) ; \quad \mathrm{SP}:$ & Kromasil & $\mathrm{C} 18$ \\
$(250 \mathrm{~mm} \times 4.6 \mathrm{~mm}, \quad 5 \mu \mathrm{m})$ & column; & WL: \\
$239 \mathrm{~nm}$; FR: $1.0 \mathrm{~mL} / \mathrm{min}$ & &
\end{tabular} & $\begin{array}{l}\text { There is no separation of compounds identi- } \\
\text { fied in the chromatogram }\end{array}$ & $\begin{array}{l}\text { Method } \\
\text { rejected }\end{array}$ \\
\hline 2 & 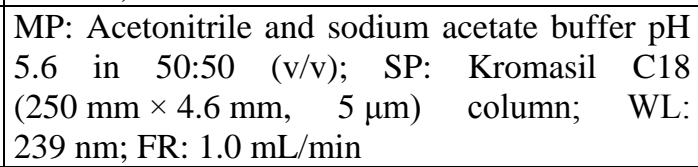 & $\begin{array}{l}\text { There is no separation of compounds identi- } \\
\text { fied in the chromatogram }\end{array}$ & $\begin{array}{l}\text { Method } \\
\text { Rejected }\end{array}$ \\
\hline 3 & $\begin{array}{l}\text { MP: triethyl amine: methanol 75:25 (v/v); SP: } \\
\text { ProntoSIL ODS C18 }(250 \times 4.6 \mathrm{~mm} ; 5 \mu \mathrm{id} \text {; WL: } \\
239 \mathrm{~nm} \text {; FR: } 1.0 \mathrm{~mL} / \mathrm{min}\end{array}$ & $\begin{array}{l}\text { Peaks were identified for standard, and im- } \\
\text { purities studied but the separation of com- } \\
\text { pounds, symmetry of the identified peaks } \\
\text { and the peak responses was very poor and } \\
\text { not acceptable }\end{array}$ & $\begin{array}{l}\text { Method } \\
\text { Rejected }\end{array}$ \\
\hline 4 & $\begin{array}{l}\text { MP: } 50 \mathrm{mM} \text { ammonium acetate, acetonitrile in } \\
25: 75(\mathrm{v} / \mathrm{v}) \text { at } \mathrm{pH} 5.9 ; \mathrm{SP} \text { : Inertsil ODS } 3 \mathrm{~V} \\
(250 \mathrm{~mm} \times 4.6 \mathrm{~mm}, 5 \mu \mathrm{m}) ; \mathrm{WL}: 239 \mathrm{~nm} \text {; FR: } \\
1.0 \mathrm{~mL} / \mathrm{min}\end{array}$ & $\begin{array}{l}\text { Peaks were identified for standard, and im- } \\
\text { purities studied but the separation of com- } \\
\text { pounds, symmetry of the identified peaks } \\
\text { and the peak responses was very poor and } \\
\text { not acceptable. }\end{array}$ & $\begin{array}{l}\text { Method } \\
\text { Rejected }\end{array}$ \\
\hline 5 & $\begin{array}{l}\text { MP: } 50 \mathrm{mM} \text { ammonium acetate, methanol in } \\
25: 75(\mathrm{v} / \mathrm{v}) \text { at } \mathrm{pH} 5.9 ; \mathrm{SP}: \text { Phenomenex Luna } \\
\mathrm{C} 18(250 \mathrm{~mm} \times 4.6 \mathrm{~mm}, 5 \mu \mathrm{m}) \text { column; WL: } \\
239 \mathrm{~nm} \text {; FR: } 1.0 \mathrm{~mL} / \mathrm{min}\end{array}$ & $\begin{array}{l}\text { The separation of compound and peak sym- } \\
\text { metry of the identified peaks was not ac- } \\
\text { ceptable }\end{array}$ & $\begin{array}{l}\text { Method } \\
\text { Rejected }\end{array}$ \\
\hline 6 & $\begin{array}{l}\text { MP: } 50 \mathrm{mM} \text { ammonium acetate, methanol in } \\
05: 95(\mathrm{v} / \mathrm{v}) \text { at } \mathrm{pH} 5.2 ; \mathrm{SP}: \text { Phenomenex Luna } \\
\mathrm{C} 18(250 \mathrm{~mm} \times 4.6 \mathrm{~mm}, 5 \mu \mathrm{m}) \text { column; WL: } \\
239 \mathrm{~nm} \text {; FR: } 1.0 \mathrm{~mL} / \mathrm{min}\end{array}$ & $\begin{array}{l}\text { Individual peaks were observed for } \\
\text { darolutamide and its impurities. The separa- } \\
\text { tion of compounds is not satisfactory and } \\
\text { peaks doesn't satisfy the system suitable } \\
\text { conditions }\end{array}$ & $\begin{array}{l}\text { Method } \\
\text { Rejected }\end{array}$ \\
\hline 7 & $\begin{array}{l}\text { MP: } 50 \mathrm{mM} \text { ammonium acetate, methanol in } \\
\text { 15:80 (v/v) at } \mathrm{pH} 5.2 ; \mathrm{SP}: \text { Phenomenex Luna } \\
\mathrm{C} 18(250 \mathrm{~mm} \times 4.6 \mathrm{~mm}, 5 \mu \mathrm{m}) \text { column; WL: } \\
239 \mathrm{~nm} \text {; FR: } 1.0 \mathrm{~mL} / \mathrm{min}\end{array}$ & $\begin{array}{l}\text { Peaks with acceptable symmetry and separa- } \\
\text { tion with acceptable system suitability was } \\
\text { identified for darolutamide and its impurities }\end{array}$ & $\begin{array}{l}\text { Method } \\
\text { Accepted }\end{array}$ \\
\hline
\end{tabular}

Note $: \mathrm{MP}=$ Mobile phase $; \mathrm{WL}=$ detector wavelength $; \mathrm{FR}=$ mobile phase flow rate.

The separation of darolutamide, impurity 1, 2 and 3 was achieved on Phenomenex column with Luna $\mathrm{C} 18(250 \mathrm{~mm} \times 4.6 \mathrm{~mm}, 5 \mu \mathrm{m})$ as stationary phase, and $50 \mathrm{mM}$ ammonium acetate : methanol solution in the ratio of 15:80 (v/v) at $\mathrm{pH} 5.2$ as mobile phase. The mobile phase was pumped in isocratic mode at a flow rate of $1.0 \mathrm{~mL} / \mathrm{min}$. The separated compounds were detected applyng UV detector at a wavelength of $239 \mathrm{~nm}$. In the optimised condition, the chromatogram observed for blank and standard was given in Figure $2 a$ and $2 b$, respectively. 


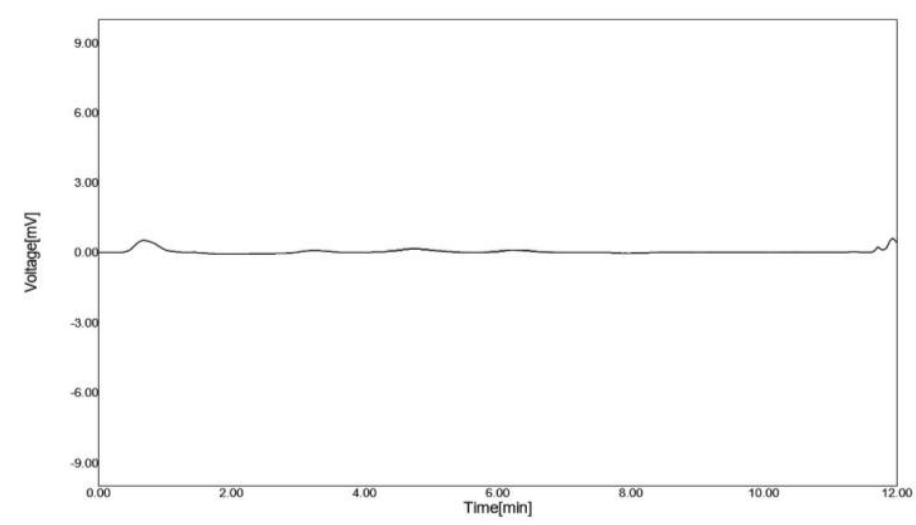

a) black chromatogram

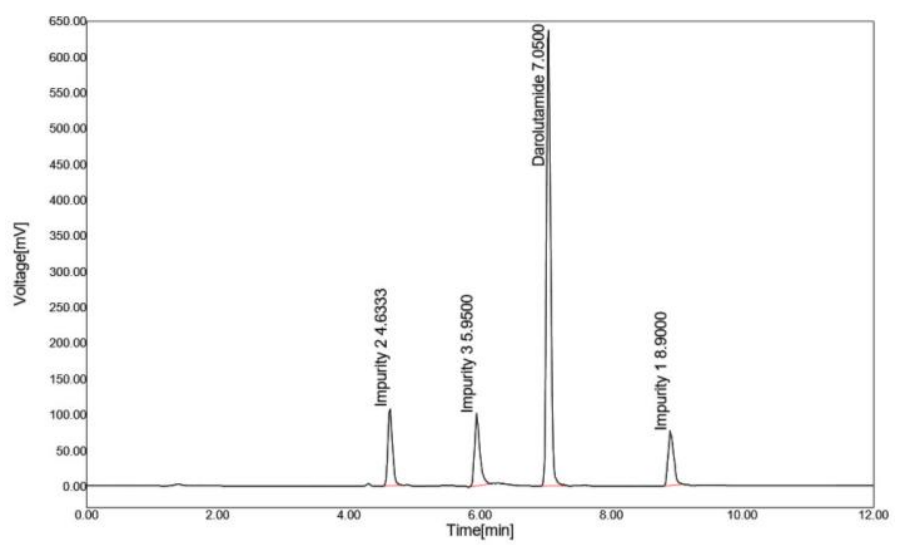

b) standard chromatogram

Figure 2. System suitability chromatograms of darolutamide, impurity 1 and 2 in the developed method

The LOD (limit of detection) was identified as $0.045 \mu \mathrm{g} / \mathrm{mL}$ for impurity 1 and $0.020 \mu \mathrm{g} / \mathrm{mL}$ for impurities 2 and 3. The limit of quantification (LOQ) was calculated as $0.15 \mu \mathrm{g} / \mathrm{mL}$ for impurity $1,0.07 \mu \mathrm{g} / \mathrm{mL}$ for impurities 2 and 3. The calibration curve was constructed from LOQ concentration i.e $0.15 \mu \mathrm{g} / \mathrm{mL}$ and the dilutions were made such that $1 \%$ of each impurity was present in the standard solution. The linear calibration curve was observed within the concentration range of $15-90 \mu \mathrm{g} / \mathrm{mL}$ for darolutamide and $0.15-$ $0.90 \mu \mathrm{g} / \mathrm{mL}$ for impurities. The regression equation was found to be

$$
\begin{aligned}
& y=15527 x+33019\left(R^{2}=0.9999\right), \\
& y=106785 x+1519.1\left(R^{2}=0.9997\right), \\
& y=161678 x+1574.3\left(R^{2}=0.9994\right) \text { and } \\
& y=123963 x+1931.9\left(R^{2}=0.9997\right)
\end{aligned}
$$

for darolutamide, impurity 1, 2 and 3 respectively. Table 3 gives the results of linearity in the developed

\begin{tabular}{|c|c|c|c|c|c|c|c|c|}
\hline \multirow{2}{*}{ S. No } & \multicolumn{2}{|c|}{ Darolutamide } & \multicolumn{2}{|c|}{ Impurity 1} & \multicolumn{2}{|c|}{ Impurity 2} & \multicolumn{2}{|c|}{ Impurity 3} \\
\hline & Con* & Peak Area & Con* & Peak Area & Con* & Peak Area & Con* & Peak Area \\
\hline 1 & 15 & 263950 & 0.15 & 17450 & 0.15 & 26887 & 0.15 & 19959 \\
\hline 2 & 30 & 502422 & 0.30 & 33026 & 0.30 & 48959 & 0.30 & 39157 \\
\hline 3 & 45 & 725137 & 0.45 & 49827 & 0.45 & 73485 & 0.45 & 58254 \\
\hline 4 & 60 & 969627 & 0.60 & 66513 & 0.60 & 98626 & 0.60 & 76459 \\
\hline 5 & 75 & 1202760 & 0.75 & 81546 & 0.75 & 124451 & 0.75 & 95683 \\
\hline 6 & 90 & 1425163 & 0.90 & 97126 & 0.90 & 146325 & 0.90 & 112563 \\
\hline
\end{tabular}
method.

Table 3

\section{Linearity results}

Note $:{ }^{*}$ Con $=$ concentration studied in $\mu \mathrm{g} / \mathrm{mL}$. 
The system suitability parameters such as the number of theoretical plates, asymmetric factor, resolution factor, retention time and relative retention time was calculated in the developed method and the results were found to be within the acceptable limit (Table 4) for darolutamide, impurity 1, 2 and 3 confirms that the method is suitable for the analysis.

Table 4

\section{System suitability results}

\begin{tabular}{|c|c|c|c|c|c|c|}
\hline \multirow{2}{*}{ Compound } & $\begin{array}{c}\text { Concentration in } \\
\mu \mathrm{g} / \mathrm{mL}\end{array}$ & $\begin{array}{c}\text { Retention Time } \\
(\mathrm{min})^{\#}\end{array}$ & RRT $^{\#}$ & $\begin{array}{c}\text { Theo } \\
\text { plate }\end{array}$ & Tail Factor & Resolution \\
\hline \multirow{3}{*}{ Darolutamide } & 45 & $7.017 \pm 0.017$ & - & 7626 & 1.08 & 5.29 \\
\cline { 2 - 7 } & 60 & $7.028 \pm 0.025$ & - & 7591 & 1.08 & 5.21 \\
\cline { 2 - 7 } & 75 & $7.033 \pm 0.017$ & - & 7685 & 1.06 & 5.25 \\
\hline \multirow{3}{*}{ Impurity 1 } & 0.45 & $8.887 \pm 0.012$ & $1.267 \pm 0.001$ & 6758 & 1.12 & 4.91 \\
\cline { 2 - 7 } & 0.60 & $8.903 \pm 0.012$ & $1.267 \pm 0.004$ & 6713 & 1.11 & 4.89 \\
\cline { 2 - 7 } & 0.75 & $8.913 \pm 0.012$ & $1.267 \pm 0.004$ & 6807 & 1.13 & 4.92 \\
\hline \multirow{3}{*}{ Impurity 2 } & 0.45 & $4.606 \pm 0.010$ & $0.656 \pm 0.001$ & 4953 & 1.09 & - \\
\cline { 2 - 7 } & 0.60 & $4.624 \pm 0.008$ & $0.658 \pm 0.001$ & 5095 & 1.08 & - \\
\hline & 0.75 & $4.626 \pm 0.009$ & $0.658 \pm 0.002$ & 4976 & 1.09 & - \\
\cline { 2 - 7 } & 0.45 & $6.022 \pm 0.067$ & $0.858 \pm 0.009$ & 9158 & 0.89 & 7.98 \\
\cline { 2 - 7 } & 0.60 & $5.978 \pm 0.035$ & $0.851 \pm 0.008$ & 9036 & 0.91 & 7.91 \\
\hline
\end{tabular}

Note: $\# \mathrm{n}=3$.

The darolutamide standard solution containing $60 \mu \mathrm{g} / \mathrm{mL}$ of darolutamide and $1 \%$ levels of each impurity was analyzed in the developed method for the evaluation of precision (repeatability) and ruggedness (reputability). The \% RSD in the peak area response was $0.12,0.25,0.20$ and 0.23 in intraday precision, $0.38,0.29,0.35$ and 0.24 in interday precision and $0.67,0.46,0.53$ and 0.36 in ruggedness respectively for darolutamide, impurity 1, 2 and 3 respectively. This confirms that the method is rugged and precise.

The robustness of the method was evaluated by analysing a standard solution containing impurities at the $1 \%$ level with small variations. The \% RSD of the peak area response was with the acceptable limit of less than 2 for darolutamide and its impurities. The system suitability conditions were also evaluated for standard, and its impurities under various conditions and results found that there was no significant change in the results observed (Table 5), which confirms the robustness of the method.

Table 5

\section{Robustness results}

\begin{tabular}{|c|c|c|c|c|c|c|c|}
\hline $\mathrm{S} \mathrm{No}$ & Compound & Change* & Peak Area & $\%$ Change & Plate Count & Tail factor & Resolution \\
\hline 1 & \multirow{6}{*}{ Darolutamide } & MP 1 & 962213 & 0.76 & 7595 & 1.09 & 5.21 \\
\hline 2 & & MP 2 & 961102 & 0.88 & 7563 & 1.07 & 5.24 \\
\hline 3 & & $\mathrm{pH} 1$ & 955093 & 1.50 & 7518 & 1.08 & 5.20 \\
\hline 4 & & $\mathrm{pH} 2$ & 963618 & 0.62 & 7527 & 1.09 & 5.19 \\
\hline 5 & & WL 1 & 956924 & 1.31 & 7533 & 1.08 & 5.22 \\
\hline 6 & & WL 2 & 962219 & 0.76 & 7539 & 1.09 & 5.23 \\
\hline 7 & \multirow{6}{*}{ Impurity 1} & MP 1 & 66011 & 0.76 & 6711 & 1.12 & 4.92 \\
\hline 8 & & MP 2 & 65594 & 1.38 & 6693 & 1.11 & 4.90 \\
\hline 9 & & $\mathrm{pH} 1$ & 66213 & 0.45 & 6685 & 1.13 & 4.91 \\
\hline 10 & & $\mathrm{pH} 2$ & 65867 & 0.97 & 6692 & 1.11 & 4.89 \\
\hline 11 & & WL 1 & 65736 & 1.17 & 6688 & 1.12 & 4.88 \\
\hline 12 & & WL 2 & 66273 & 0.36 & 6676 & 1.10 & 4.95 \\
\hline 13 & \multirow{6}{*}{ Impurity 2} & MP 1 & 98577 & 0.05 & 4868 & 1.09 & - \\
\hline 14 & & MP 2 & 97211 & 1.43 & 4891 & 1.08 & - \\
\hline 15 & & $\mathrm{pH} 1$ & 98016 & 0.62 & 4873 & 1.09 & - \\
\hline 16 & & $\mathrm{pH} 2$ & 98258 & 0.37 & 4809 & 1.07 & - \\
\hline 17 & & WL 1 & 97732 & 0.91 & 4833 & 1.09 & - \\
\hline 18 & & WL 2 & 98558 & 0.07 & 4932 & 1.07 & - \\
\hline
\end{tabular}


Development and validation of a novel stability ...

\begin{tabular}{|c|c|c|c|c|c|c|c|}
\hline \multicolumn{8}{|c|}{ Continuation } \\
\hline $\mathrm{S} \mathrm{No}$ & Compound & Change* & Peak Area & $\%$ Change & Plate Count & Tail factor & Resolution \\
\hline 19 & \multirow{6}{*}{ Impurity 3} & MP 1 & 75860 & 0.78 & 9027 & 0.88 & 7.91 \\
\hline 20 & & MP 2 & 75955 & 0.66 & 9063 & 0.89 & 7.95 \\
\hline 21 & & $\mathrm{pH} 1$ & 75564 & 1.17 & 9012 & 0.88 & 7.93 \\
\hline 22 & & $\mathrm{pH} 2$ & 75722 & 0.96 & 9106 & 0.90 & 7.92 \\
\hline 23 & & WL 1 & 75290 & 1.53 & 9089 & 0.91 & 7.95 \\
\hline 24 & & WL 2 & 76155 & 0.40 & 9099 & 0.89 & 7.93 \\
\hline
\end{tabular}

Note: * MP (mobile phase) 1: $50 \mathrm{mM}$ ammonium acetate : methanol in 10:90 (v/v); MP 2: $50 \mathrm{mM}$ ammonium acetate : methanol in 25:75 (v/v); WL (wavelength) 1: $244 \mathrm{~nm}$; WL 2: $234 \mathrm{~nm} ; \mathrm{pH}$ 1: 5.3; pH 2: 5.1 .

Accuracy of the method was performed by spiked recovery at $50 \%, 100 \%$ and $150 \%$ spiked levels of target $30 \mu \mathrm{g} / \mathrm{mL}$ of darolutamide and $0.30 \mu \mathrm{g} / \mathrm{mL}$ of each impurity studied. An acceptable \% recovery in each analysis, \% RSD in each spiked level was observed (Table 5) for darolutamide, impurities 1, 2 and 3. This confirmed the accuracy of the method.

Table 5

Recovery results

\begin{tabular}{|c|c|c|c|c|c|c|c|c|}
\hline \multirow{2}{*}{ S. No } & \multirow{2}{*}{ Compound } & \multirow{2}{*}{$\begin{array}{l}\text { Recovery } \\
\text { Level }\end{array}$} & \multicolumn{3}{|c|}{ Concentration in $\mu \mathrm{g} / \mathrm{mL}$} & \multirow{2}{*}{$\begin{array}{l}\text { Amount found* } \\
\text { Mean } \pm \text { SD }\end{array}$} & \multirow{2}{*}{$\begin{array}{c}\% \text { recovered } * \\
\text { Mean } \pm \mathrm{SD}\end{array}$} & \multirow{2}{*}{$\begin{array}{l}\text { \% RSD of } \\
\text { Recovery }\end{array}$} \\
\hline & & & Target & Spiked & Final & & & \\
\hline 1 & \multirow{3}{*}{ Darolutamide } & $50 \%$ & 30 & 15 & 45 & $44.679 \pm 0.237$ & $99.29 \pm 0.526$ & 0.53 \\
\hline 2 & & $100 \%$ & 30 & 30 & 60 & $59.604 \pm 0.177$ & $99.34 \pm 0.295$ & 0.30 \\
\hline 3 & & $150 \%$ & 30 & 45 & 75 & $74.105 \pm 0.416$ & $98.81 \pm 0.555$ & 0.56 \\
\hline 4 & \multirow{3}{*}{ Impurity 1} & $50 \%$ & 0.30 & 0.15 & 0.45 & $0.446 \pm 0.003$ & $99.08 \pm 0.600$ & 0.61 \\
\hline 5 & & $100 \%$ & 0.30 & 0.30 & 0.60 & $0.597 \pm 0.002$ & $99.42 \pm 0.303$ & 0.30 \\
\hline 6 & & $150 \%$ & 0.30 & 0.45 & 0.75 & $0.739 \pm 0.002$ & $98.52 \pm 0.330$ & 0.34 \\
\hline 7 & \multirow{3}{*}{ Impurity 2} & $50 \%$ & 0.30 & 0.15 & 0.45 & $0.446 \pm 0.002$ & $99.14 \pm 0.499$ & 0.50 \\
\hline 8 & & $100 \%$ & 0.30 & 0.30 & 0.60 & $0.594 \pm 0.003$ & $98.98 \pm 0.555$ & 0.56 \\
\hline 9 & & $150 \%$ & 0.30 & 0.45 & 0.75 & $0.740 \pm 0.001$ & $98.61 \pm 0.147$ & 0.15 \\
\hline 10 & \multirow{3}{*}{ Impurity 3} & $50 \%$ & 0.30 & 0.15 & 0.45 & $0.447 \pm 0.002$ & $99.32 \pm 0.398$ & 0.40 \\
\hline 11 & & $100 \%$ & 0.30 & 0.30 & 0.60 & $0.591 \pm 0.001$ & $98.51 \pm 0.208$ & 0.21 \\
\hline 12 & & $150 \%$ & 0.30 & 0.45 & 0.75 & $0.744 \pm 0.003$ & $99.26 \pm 0.397$ & 0.40 \\
\hline
\end{tabular}

Note: $* n=3$.

The stress degradation study confirms that in UV light degradation illustrates high percentage degradation followed by base degradation. In acid degradation, the \% degradation of darolutamide was $8.59 \%$ and six degradation compounds were identified and retained at a retention time of 2.0, 5.4, 6.6, 7.5, 9.5, and $10.0 \mathrm{~min}$. In this degradation study the impurity 2 was identified at a retention time of $4.6 \mathrm{~min}$ and the other impurities studied were not detected (Fig. 3). In base degradation study, $9.03 \%$ degradation was observed for darolutamide. Also 5 degradation compounds were identified at a retention time of 3.5, 4.3, 5.6, 7.6 and $9.6 \mathrm{~min}$. In this study, the impurity 2 was identified and retained at a retention time of $4.6 \mathrm{~min}$ (Fig. 4). The $\%$ degradation of $7.85 \%$ was observed in peroxide degradation study. Here five degradation compounds were separated along with impurities 2 and 3 (Fig. 5). Among all the degradation conditions studied, a very less $\%$ degradation of $6.91 \%$ was observed in thermal degradation. In this condition, four degradation compounds were identified and impurities 2 and 3 were also detected (Fig. 6). A very high \% degradation of $9.57 \%$ was observed in UV light degradation study. In this study impurity 3 was identified along with six degradation compounds (Fig. 7). In all the stress degradations studied, the degradation compounds were well resolved and retained in the developed method. There is no interference of the unknown degradation compounds with the known impurities in the study as well as the standard darolutamide. This confirms that the method is effectively separates the known impurities and unknown degradation compounds formed during the stress study confirms the stability indicating nature of the method. 


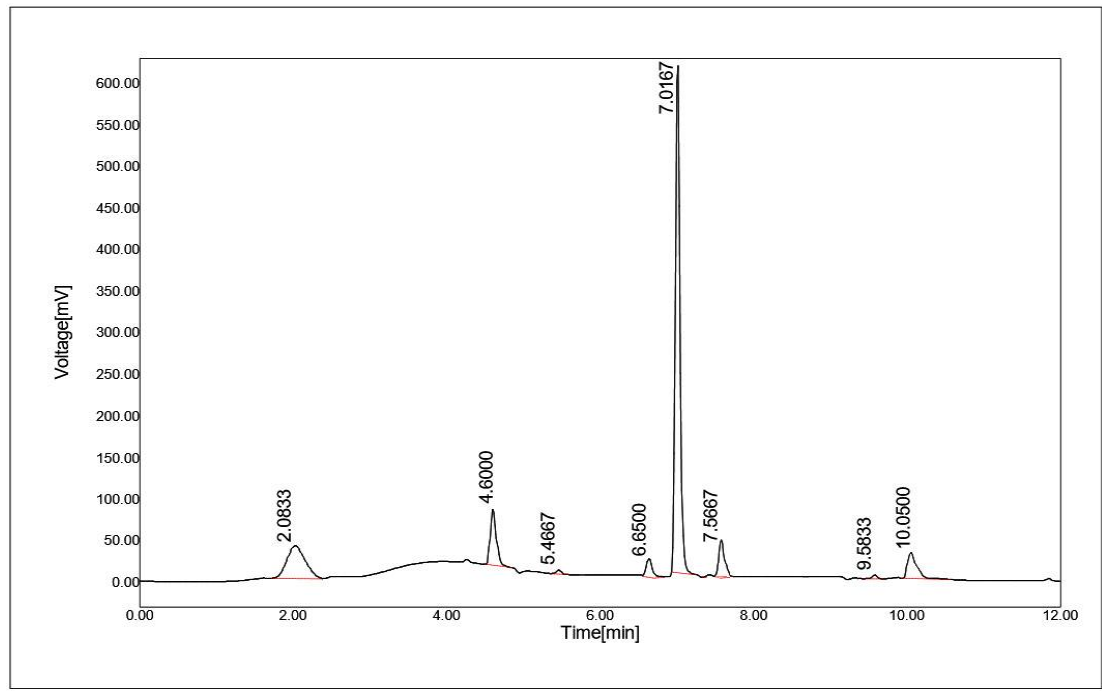

Figure 3. Acid degradation chromatogram of darolutamide

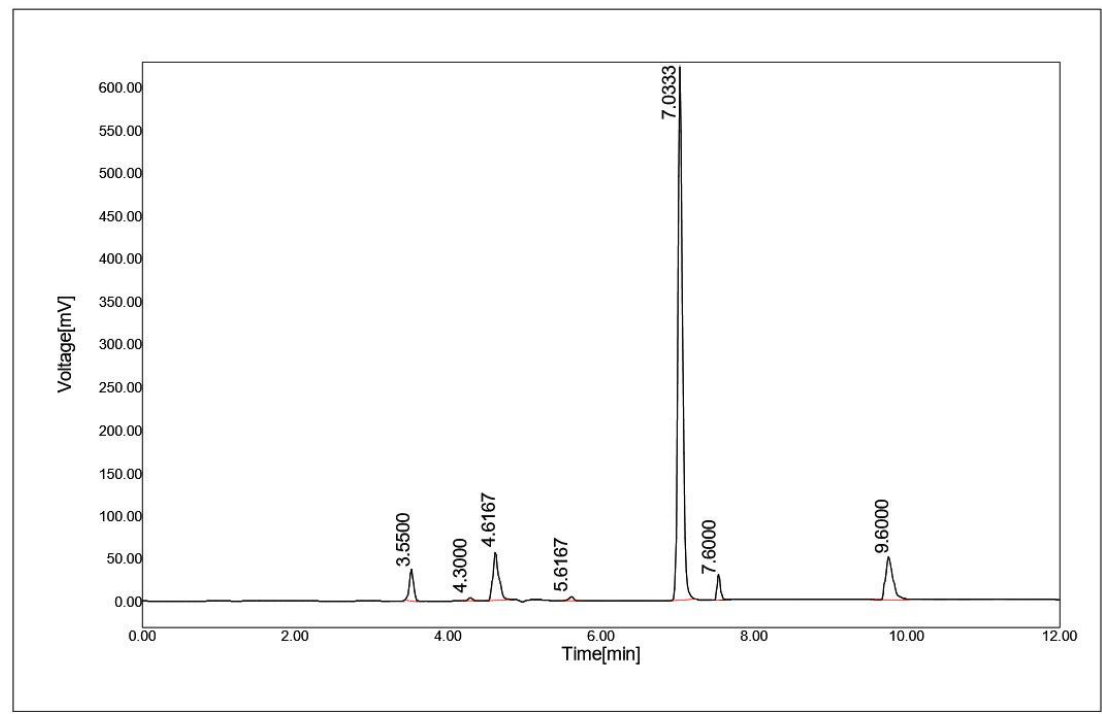

Figure 4. Base degradation chromatogram of darolutamide

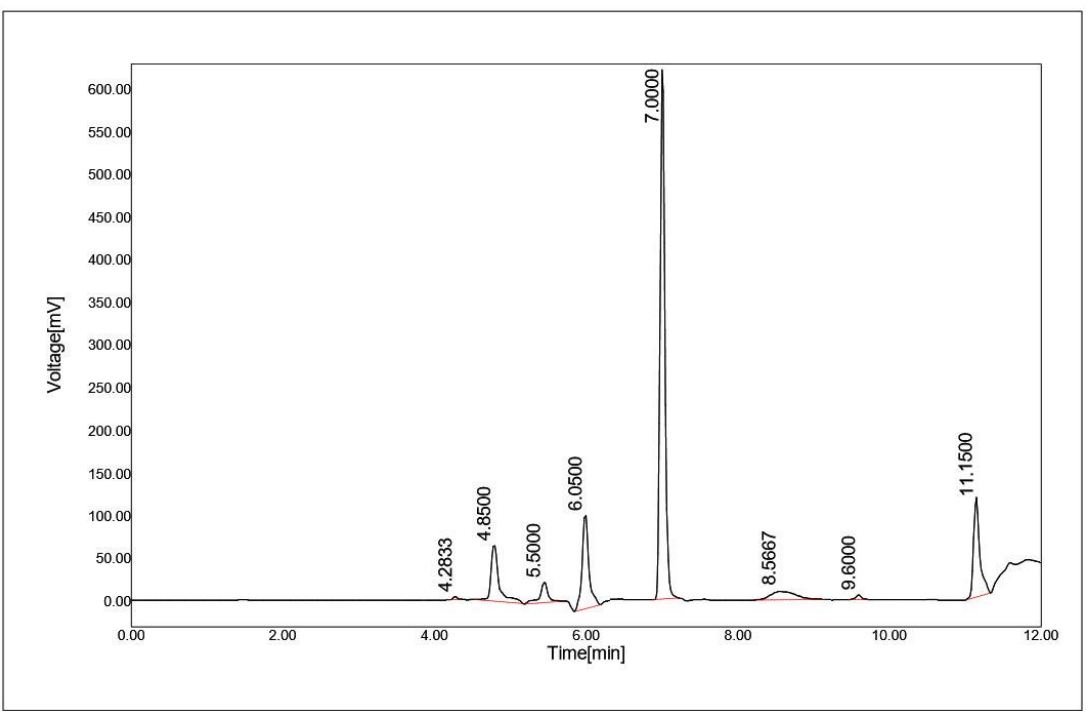

Figure 5. Peroxide degradation chromatogram of darolutamide 


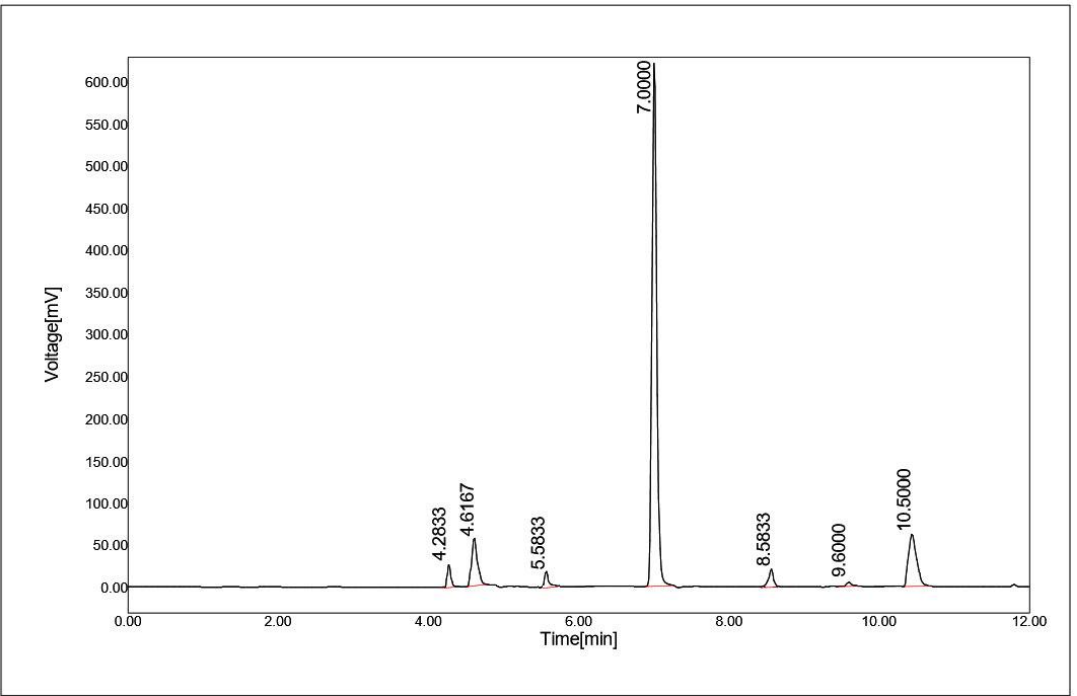

Figure 6: Thermal degradation chromatogram of darolutamide

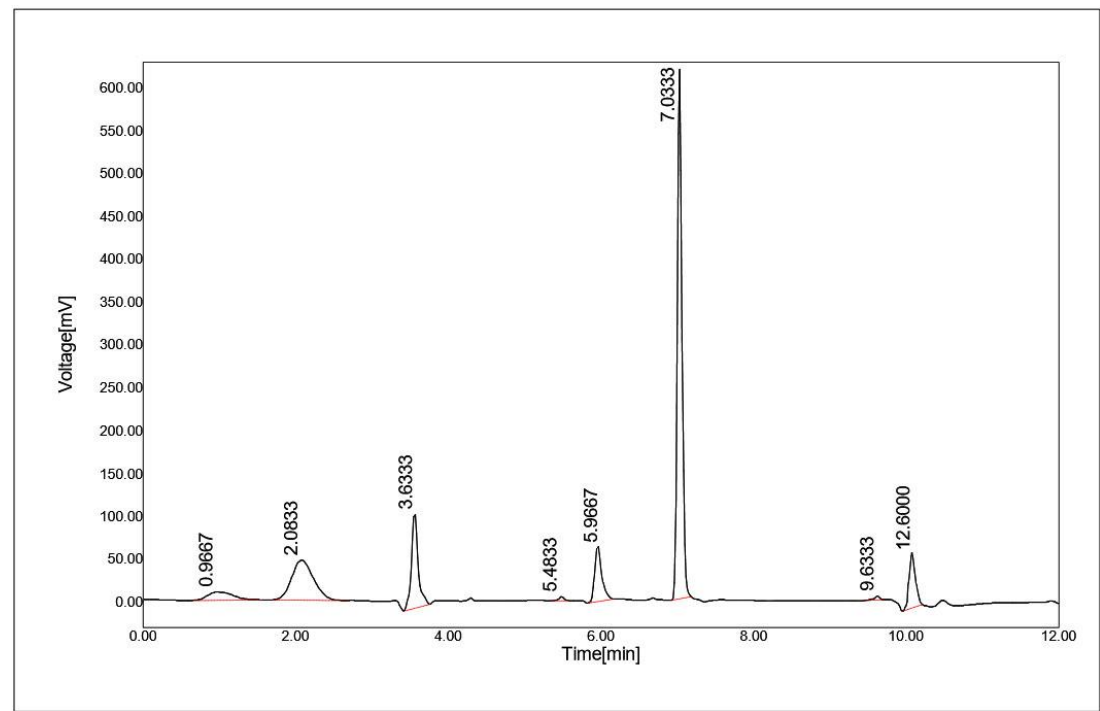

Figure 7. UV light degradation chromatogram of darolutamide

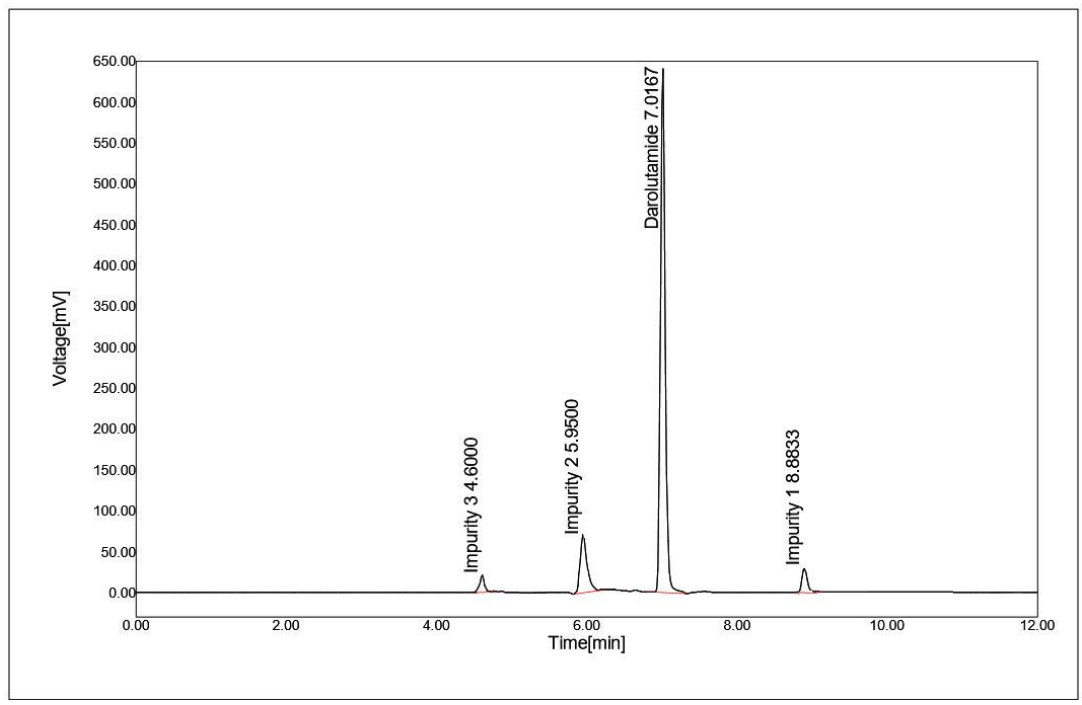

Figure 8. Formulation chromatogram of darolutamide 
The method developed in the present study is applied for the estimation of darolutamide, impurities 1,2 and 3 in pharmaceutical formulation. The $\%$ assay in formulation sample was observed to be $98.58 \%, 0.08$, 0.24 and $0.12 \%$ for darolutamide, impurities 1,2 and 3 respectively. In the formulation chromatogram (Fig. 8), the formulation excipients were not detected and the retention time of darolutamide and its impurities. The impurities were observed to be within the acceptable limit and prove that the method is applicable for the routine analysis of darolutamide and its impurities.

\section{Conclusion}

A simple, novel, and robust analytical RP-HPLC method developed and satisfactorily validated the validation parameters such as accuracy, ruggedness, robustness, and system suitability for the separation and simultaneous quantification of darolutamide and its known impurities 1,2 , and 3 . The method having a sensitive linearity range of $0.15-0.90 \mu \mathrm{g} / \mathrm{mL}$ for impurities, as well as $15-90 \mu \mathrm{g} / \mathrm{mL}$ for darolutamide. Meanwhile, the method successfully separates the unknown degradation compounds formed during forced degradation study along with known impurities. Hence, it can be concluded that the method is stable and suitable for the separation and simultaneous quantification of darolutamide and its impurities in bulk drug, as well as formulations.

\section{References}

1 Mowszowicz (1989). Antiandrogens. Mechanisms and paradoxical effects, Ann. Endocrinol. Paris., 50(3), $189-199$.

2 Lieberman, R. (2001). Androgen deprivation therapy for prostate cancer chemoprevention: current status and future directions for agent development, Urology, 58(2), 83-90 https://doi.org/10.1016/S0090-4295(01)01247-X

3 Sciarra F., Toscano, V., Concolino, G., \& Di Silverio, F. (1990). Antiandrogens: clinical applications, J. Steroid Biochem. Mol. Biol., 37(3), 349-362 https://doi.org/10.1016/0960-0760(90)90484-3

4 Fizazi, K., Smith, M.R., \& Tombal, B., (2018). Clinical Development of Darolutamide: A Novel Androgen Receptor Antagonist for the Treatment of Prostate Cancer, Clin Genitourin Cancer., 16(5), 332-340 https://doi.org/10.1016/j.clgc.2018.07.017

5 Liang, D., Richard, C.Z., Wei, X., Theo, M.R., \& Kenneth, J.P. (2019). Metastatic prostate cancer remains incurable, why?, Asian J Urol., 6(1), 26-41 https://doi.org/10.1016/j.ajur.2018.11.005

6 Samia Rocha de Oliveira Melo, Mauricio Homem-de-Mello, Damaris Silveira \& Luiz Alberto Simeoni, (2014). Advice on Degradation Products in Pharmaceuticals: A Toxicological Evaluation, PDA J Pharm Sci Technol., 68(3), 221-238 https://doi.org/10.5731/pdajpst.2014.00974

7 Ashok, Z., Vinay, K., Umesh, T., Suresh, P.S., \& Ramesh, M., (2018). RP-HPLC-UV Method for Simultaneous Quantification of Second Generation Non-Steroidal Antiandrogens Along with their Active Metabolites in Mice Plasma: Application to a Pharmacokinetic Study, Drug Res., 69(10), 537-544 https://doi.org/10.1055/a-0790-8309

8 Neraj, K.S., Suresh, P.S., Mohd, Z., \& Ramesh, M. (2018). Development and validation of a novel method for simultaneous quantification of enzalutamide, darolutamide and their active metabolites in mice dried blood spots using LCMS/MS: application to pharmacokinetic study in mice, ADMET \& DMPK, 6(3), 242-257 https://doi.org/10.5599/admet.557

9 Sreekanth, D, Pavan, K.V.S.P.N., Suresh, P.S., Syed, M. S., Sadanand, R. M., \& Mohd, Z., et al. (2017) LC-MS/MS-ESI method for simultaneous quantification of darolutamide and its active metabolite, ORM-15341 in mice plasma and its application to a pharmacokinetic study, J. Pharm. Biomed. Anal., 145, 454-461. https://doi.org/10.1016/j.jpba.2017.06.074

10 Suresh, P.S., Neeraj, K.S., Prasanthi, D., Sai, B.P., \& Ramesh, M. (2018). Validation of an LC-MS/MS method for simultaneous quantitation of enzalutamide, $\mathrm{N}$-desmethylenzalutamide, apalutamide, darolutamide and ORM-15341 in mice plasma and its application to a mice pharmacokinetic study, J. Pharm. Biomed. Anal., 156, 170-180. https://doi.org/10.1016/j.jpba.2018.04.038

11 Narayanan, B., Suresh, P.S., Neeraj, K.S., Siva, K.A., \& Ramesh, M. (2018). Validation of a chiral LC-MS/MS-ESI method for the simultaneous quantification of darolutamide diastereomers in mouse plasma and its application to a stereoselective pharmacokinetic study in mice, Biomed. Chromatogr., 1-8. https://doi.org/10.1002/bmc.4173

12 Bikshal, B.K., Useni, R.M., Venkateswara, R.A., \& Maheshwara, R.L., (2018). Intended high-performance liquid chromatography procedure for the quantification of norfloxacin and its potential impurities in active pharmaceutical ingredient and tablet dosage forms, Thai J. Pharm. Sci., 42(1), 27-36.

13 Mallu, U.R., Anna, V.R., \& Kasimala, B.B. (2019). Rapid Stability Indicating HPLC Method for the Analysis of Leflunomide and Its Related Impurities in Bulk Drug and Formulations, Turk J Pharm Sci., 16, 457-465 https://doi.org/10.4274/tjps.galenos.2018.34635

14 Prasad, S.S., Krishna Mohan, G.V., \& Naga Babu, A., (2019). Development of simple and robust RP-HPLC method for determination of everolimus and its impurities in oral solid dosage form, Asian J. Chem., 31(5), 1002-1008 https://doi.org/10.14233/ajchem.2019.21723

15 Palacharla, S.K., \& Krishna Mohan, G.V. (2019). HPLC method for determination of aspirin, rosuvastatin, ezetimibe and clopidogrel in combination drug products, Asian J. Chem., 31(10), 2275-2283 https://doi.org/10.14233/ajchem.2019.22050 
16 Palacharla, S.K., Krishna Mohan, G.V., \& Naga Babu, A. (2019). RP-HPLC estimation of bumetanide and its impurities in oral solid dosage form, Asian J. Chem., 31(10), 2275-2283 https://doi.org/10.14233/ajchem.2019.22069

17 Bikshal, B.K., Venkateswara, R.A., \& Useni, R.M. (2018). Stability-Indicating Reversed-Phase HPLC Method for the Separation and Estimation of Related Impurities of Cilnidipine in Pharmaceutical Formulations, Indian Drugs, 55(12), 41-49.

18 Sri Girija, K., Bikshal, B.K., \& Venkateswara, R.A. (2021). A new high-performance liquid chromatography method for the separation and simultaneous quantification of eptifibatide and its impurities in pharmaceutical injection formulation, Int $J$ App Pharm., 13(2), 165-172 https://doi.org/10.22159/ijap.2021v13i2.39895

\author{
В.Г. Камани, М. Суджата, Г. Даддала
}

\title{
Даролутамид пен оның фармацевтикалық препараттардағы қоспаларын бөлу және анықтау үшін жаңа сенімді жТСХ әдісін жасау және валидациялау
}

\begin{abstract}
Мақалада даролутамид пен оның 1, 2, 3 қоспаларын жеке күйінде және қосылыстарда талдаудың жаңа сенімді ҚФ-ЖТСХ әдісі алғаш рет ұсынылған. Бөліну тұрақты фаза ретінде Luna C18 (250 мм × 4,6 мм, 5 мкм) және жылжымалы фаза ретінде 50 мМ аммоний ацетаты ерітіндісі мен метанолдың 15:80 қатынасында (көлем/көлем) Phenomenex мұнарасында іске асырылды $(\mathrm{pH}=5,2$ және ағын жылдамдығы 1,0 мл/мин). УК анықтау 239 нм толқын ұзындығында орындалды. Осы жағдайларда даролутамид пен оның 1, 2 және 3-ші қоспаларының ұсталу уақыты сәйкесінше 7,05, 8,90, 4,63 және 5,95 мин болды. Әдіс жүйелік жарамдылыққа, талдау ауқымына, дәлдігіне, ерекшелігіне, тұрақтылығына және сенімділігіне тексерілді. Мәжбүрлі деградацияны зерттеу талданатын затты бес түрлі стресс жағдайына ұшырату арқылы жүргізілді және деградацияның барлық жағдайларында ыдырау \%-ы өте төмен болды. Ұсынылған әдіс дәрілік затты және оның фармацевтикалық құрамдағы қоспаларын бөлуге және бағалауға мүмкіндік береді. Жалпы, әзірленген әдіс даролутамидті сандық анықтауға жарамды екені және 1, 2 және 3 қоспаларды бөлуге, сондай-ақ талдауға мүмкіндік беретіні көрсетілді.
\end{abstract}

Кілт сөздер: даролутамид, қоспаларды талдау, ЖТСХ әдісі, әдісті валидациялау, валидация, мәжбүрлі ыдырауды зерттеу, құрамды талдау, Nubeqa® ішіндегі қоспаларды талдау.

\section{В.Г. Камани, М. Суджата, Г. Даддала \\ Разработка и валидация нового надежного метода ВЭЖХ для разделения и определения даролутамида и его примесей в фармацевтических препаратах}

\begin{abstract}
В статье впервые представлен новый надежный ОФ-ВЭЖХ метод анализа даролутамида и его примесей $1,2,3$ в индивидуальном виде и в композициях. Разделение было достигнуто на колонке Phenomenex c Luna C18 (250 мм × 4,6 мм, 5 мкм) в качестве стационарной фазы и раствора 50 мМ ацетата аммония : метанола, соотношением 15:80 (объем/объем) в качестве подвижной фазы ( $\mathrm{pH}=5,2$, скорость потока 1,0 мл/мин). УФ-детектирование осуществлялось при длине волны 239 нм. В этих условиях время удерживания даролутамида и его примесей 1,2 и 3 составило 7,05, 8,90, 4,63 и 5,95 мин соответственно. Метод был проверен на системную пригодность, диапазон анализа, точность, специфичность, стабильность и надежность. Исследование принудительной деградации проводилось путем воздействия на аналит пяти различных стрессовых условий, и во всех условиях деградации процент разложения был очень низким. Предложенный метод позволяет разделять и оценивать лекарственное средство и его примеси в фармацевтических составах. В целом, было показано, что разработанный метод подходит для количественного определения даролутамида и разделения и анализа примесей 1,2 и 3.
\end{abstract}

Ключевые слова: даролутамид, анализ примесей, разработка метода ВЭЖХ, проверка метода, валидация, исследование принудительного разложения, анализ состава, анализ примесей в Nubeqa®.

\section{Information about authors}

Venu Gopal Kamani - PhD student, Department of of Chemistry, Koneru Lakshmaiah Education Foundation, Vaddeswaram, Guntur — 522502, A.P., India; e-mail: venukamani@gmail.com; https://orcid.org/0000-0002-1834-7227; 
Dr. M. Sujatha - Associate Professor, Department of of Chemistry, Koneru Lakshmaiah Education Foundation, Vaddeswaram, Guntur — 522502, A.P., India; e-mail: sujathaenviero@kluniversity.in; https://orcid.org/0000-0001-9645-3298;

Guna Bhushana Daddala - Chief Scientist, Department of Analytical and Research, Piramal Pharma Ltd, Ennore, Chennai — 600057, Tamil Nadu, India; e-mail: gunabhushana.daddala@ piramal.com; https://orcid.org/0000-0001-5878-1653. 